\title{
PLANETS, PULSARS, AND POETRY
}

\author{
S.B. Yorka \\ Denison University, Granville, Ohio 43023, U.S.A.
}

For many of us in the United States, the majority of our students are in descriptive astronomy classes. And since these classes typically satisfy general education or core curriculum requirements that must be completed by all students, the students can range from those genuinely interested in astronomy to those who are taking the class because "it sounded less boring" than other options available. Whichever end of that spectrum the students occupy, many of them approach astronomy with quite a bit of anxiety because it is a science class. In student lore, a science class is a class that is by definition more difficult - perhaps verging on the impossible - than other classes, one that discusses totally foreign things in an arcane language and, above all, is a class that has no connection with anything else in the curriculum, except maybe another science class.

We all would probably concede that many non-science students do find science classes more difficult than their humanities or arts classes - primarily because of poor math and critical reasoning skills. And to students who do not read Scientific American, or Science News, or even the science section of magazines or newspapers, words like supernova, quarks, and quasars are indeed foreign. Nor is there a lot we can do in a semester course in astronomy to markedly improve math skills or change life-long reading (or non-reading) habits. But what we certainly can do is help the students to make connections - to become aware of the ways in which science courses can relate to, illuminate, and enhance material encountered in arts and humanities courses.

That is the purpose of "Planets, Pulsars, and Poetry," which is one of a series of interdisciplinary exercises designed for astronomy students in a liberal-arts curriculum. The exercise introduces the students to specific poems that can only be fully appreciated if the reader has some knowledge of astronomy. The poems - by 20th century American poets - are chosen for their use of astronomical phenomena as subjects or metaphors. The students are asked some questions about the general characteristics of each poem; but since it is desired that the students put to use their knowledge of astronomy, they are questioned more closely about the astronomical aspects of each poem. They are asked to analyze each poem with respect to its astronomical allusions: they must explain the general meaning of the whole poem and the meaning of any astronomical terms, and are usually asked to give detailed explanations of particularly interesting passages. Each poem is accompanied by a set of questions designed to direct the students' attention to specific parts of the poem, leading them to a better understanding of the poem as a whole. The exercise is scheduled about halfway through the semester so that the students have a background sufficient to allow them to understand some of the terms that they may not 
yet have encountered, such as redshift, pulsar, and big bang. The poems currently in use in this and a couple of other interdisciplinary exercises concern phases of the moon, a lunar eclipse, planets, constellations, the night sky, pulsars, the Voyager II satellite, and a whimsical comparison between astronomy and astrology.

Perhaps the most transparent of the poems - and a favorite of the students - is Robert Frost's "Two Leading Lights," which contrasts the sun and the moon. The sun is "satisfied with days" and has "the greatness to refrain" from appearing at night while

"The moon for all her light and grace

Has never learned to know her place";

and while astronomers

"Have set the dark aside for hers

...there are many nights, though clear

She doesn't bother to appear.

Some lunatic or lunar whim

Will bring her out, diminished dim,

To set herself beside the sun...."

The obvious concepts the students need to explain this poem are the daily rotation of the Earth and the role of the revolution of the moon around the Earth in producing the "lunatic" behavior of the moon. Observations of lunar phases are carried out earlier in the semester, so the students have seen this behavior for themselves and have had to explain the phases of the moon.

Another poem the students enjoy is "Saturn" from The Planets by Diane Ackerman. The students are asked to explain Saturn appearing as "An elliptical blur...' creeping into the field of view "Bellowing light," lying "... stunned in a hall of mirrors, hog-tied by the cross hairs." The second stanza concerns the rings:

"Millions of vest-pocket moons

hang together as rings

that loop around the planet

like a highway skirting the golden city,

dusky bright, and godawful sheer,

They dog the equator (like Uranus's moons) never more than

two miles thick: a sprawling coral reef of tailless comets

Grinding one another

finer and finer, lolloping boulder

to dusty mote as, eddying

down through the crepiest ring

they pour into a gassy draw."

The students are asked to provide a detailed analysis of this and three other stanzas from "Saturn." All of the stanzas have the same physical appearance, with 
five short lines, two longer lines, and five short lines as the author obviously shaped the poem to resemble Saturn and its rings. Oddly enough, very few students notice that.

More subtle phrases are encountered by the students in other poems:

"...clouds of our unknowing like great nebulae"

"As through a glass that magnifies my loss

I see the lines of your spectrum shifting red...."

"Science of the Night" by Kunitz

"The tin man is cold, the glitter of distant worlds

is like snow on his coat..."

"...the white, elusive

dandelion fuzz

of starlight..."

"Voyager II Satellite" by Kooser

"... ancient stream of starlight... has made its way to our eyes through... downcurved ravines of space..."

"By Starlight" by Wagoner

The rich complexity encompassed by the description of stars as "taillights of the big bang..." (Saner) is rarely appreciated by students on their own, and a discussion of the phrase helps the students follow a chain from cosmology to stellar evolution.

Student reaction to this exercise has ranged from pleased incredulity (from English majors in the class) to downright hostility (from a student who was incensed that he was going to be expected to write a paper - and be graded on grammar and spelling - in a science class). The majority of the students, though, have responded very favorably, and are delighted that their knowledge of astronomy enables them to decipher poetry that they know they wouldn't have understood prior to taking the class. Perhaps one measure of the success of this exercise in reaching students in a way unusual in science classes is exemplified by the student who signed up for an astronomy class for next fall - because of the "poetry lab," as the students call it.

A short bibliography of poetry used accompanies this paper; a more extensive listing of "astronomical poetry," as well as copies of the full exercise "Planets, Pulsars, and Poetry" are available from the author. 


\section{Reading List}

Ackerman, Diane, "Saturn" from The Planets: A Cosmic Pastoral (Morrow Quill Paperbacks, 1976).

Frost, Robert, "Two Leading Lights" and "Upon Looking Up by Chance at the Constellations", from Complete Poems of Robert Frost 1949 (Henry Holt \& Co., 1949).

Hollander, John, "The Great Bear" from Spectral Emanations (Athenum, 1978).

Kerr, Minnie Markham, "Nocturne" from The Music Makers, complied by Stanton Coblentz (B. Ackerman Inc., 1945).

Kirby, Inez, "Silence" and "Night Unto Night" from The Music Makers, complied by Stanton Coblentz (B. Ackerman Inc., 1945).

Kooser, Ted, "The Voyager II Satellite" from One World at a Time (University of Pittsburgh Press, 1985).

Kunitz, Stanley, "Science of the Night" from The Poems of Stanley Kunitz 19281978 (Little, Brown \& Co., 1979).

Rich, Adrienne, "Planetarium" and "For the Conjunction of Two Planets" from Adrienne Rich's Poetry, ed. B. Gelpi and A. Gelpi (W.W. Norton Co., 1975).

Saner, Reg, "That Line Drawn at the Moon" from Climbing into the Roots (Harper and Row Publ., 1976).

Wagoner, David, "By Starlight" from First Light (Little, Brown \& Co., 1983).

\section{Discussion}

L.C. Hill, Jr.: I would like your comment on a phenomenon that I have observed in student responses to astronomical materials. I have found that in student essays (and, in a few cases, in student paintings) some students show a grasp of astronomical topics and their implications that I would never have imagined simply from their responses to mathematical or more traditionally scientific examinations.

S. Yorka: Yes, I agree that some students do show in written assignments a level of understanding higher than one would expect from the results of traditional exams.

\section{Comment}

Jay M. Pasachoff: Two noted American poets, Anthony Hecht and John Hollander, decided that it was a pity that art forms could not usually point to a moment of discovery the way science can. At what instant was the sonnet invented, for example? They decided to rectify this failing of poetry by inventing a new poetry form while reporting on the process. The result was a form of poetry called a "double dactyl," which has several strict rules: Each line is made of two dactyl (a dactyl is DAH dah dah), and there are two stanzas, each of four lines. The first stanza begins with a double-dactyl nonsense line like "Jiggery-pokery." One line in the first stanza is a single double-dactyl word. They keep an official list of such names and words, which cannot be reused in other double-dactyl poems. Their published "canon" was 
published as Jiggery-Pokery, A Compendium of Double Dactyls, edited by Anthony Hecht and John Hollander (New York: Atheneum, 1967), and included (including the footnote):

Revolutionist by Nancy L. Stark

\author{
Higgledy-piggledy \\ Nic'laus ${ }^{1}$ Copernicus \\ Looked at the Universe, \\ Spoke to the throng: \\ Give up your Ptolemy, \\ Rise up and follow me, \\ Heliocentrically \\ Ptolemy's wrong.
}

My own effort is: (about the pulsar CP 03282)

Higgledy-piggledy

CP0329

Pulsing its message

To us from afar.

Is it a message from

Extraterrestrial

Little green men

On a dense neutron star?

Note from Editor John Percy: Jay (perhaps understandably) did not mention his even more famous effort, which appears as part of the Biographical Notes to his article on "The Solar Corona" in Scientific American, October 1973:

Higgledy piggledy

Jay Myron Pasachoff

Williams astronomer

Dabbles in rhyme

Solar eclipses and

Radiotelescopes

Keep him contented

The rest of the time.

\footnotetext{
${ }^{1}$ This is clearly cheating; on the other hand, "Nicky" would have been far, far worse. Lines 5 and 6 are nevertheless inspired.

${ }^{2}$ (This appeared in Physics Today and was anthologized in A Random Walk in Science.)
} 